\title{
No One Even Has Eyes: The Decline of Hand-Painted Graphics in Mumbai
}

\section{Aaron Fine}

\begin{abstract}
In this work of creative non-fiction, accompanied by coloring book plates of his own design, the author explores recent changes in Indian visual culture. An investigation of hand-painted political graphics in Mumbai revealed very little painting and a great deal about the rapidly advancing digitalization of visual space in India. As idiosyncratic and individual creative efforts are replaced by massproduced digital printing, in what ways are India's political networks enhanced; in what ways are India's creative networks destroyed? Translators, police officers, political activists, and artists are presented through the eyes of an outsider whose own expectations about creative expression and political participation are challenged. The conclusion considers how once recycled visual culture artifacts are now junk destined for the landfill, and urges readers to color-in the whitewashed spaces of the city.
\end{abstract}

Keywords India; political graphics; waste stream; digital technology

Someone has painted over the city. Men in uniform coveralls and orange trucks embellished with "Clean Up Mumbai!" are now sweeping the streets clean of rubbish. What will the ragpickers do when the new trash service has succeeded in cleaning the city?

There used to be signs here, painted on these walls, claiming this or that piece of the city as the turf of some political party. Today the paintings are mostly gone. They have been whitewashed, or rather they have been painted over in various hues of thick cheap opaque paint. In places, this paint chips and flakes away. Other spots are scratched, gouged, or simply worn down by sun, time, and monsoon. The result is a beautiful palimpsest - a sense of history's textures.

Where did the sign painters go?

In the summer of 2009, I traveled to Mumbai to study the hand-painted political graphics of India. I had many promising questions to pursue: questions about literacy, political participation, and freedom of expression; questions about property rights, political thuggery, and vandalism. I wanted to ask: How important are these forms of visual communication in a country where many are illiterate and many different writing systems are used? Who is empowered to create these acts of political expression? How do the private property rights of the people

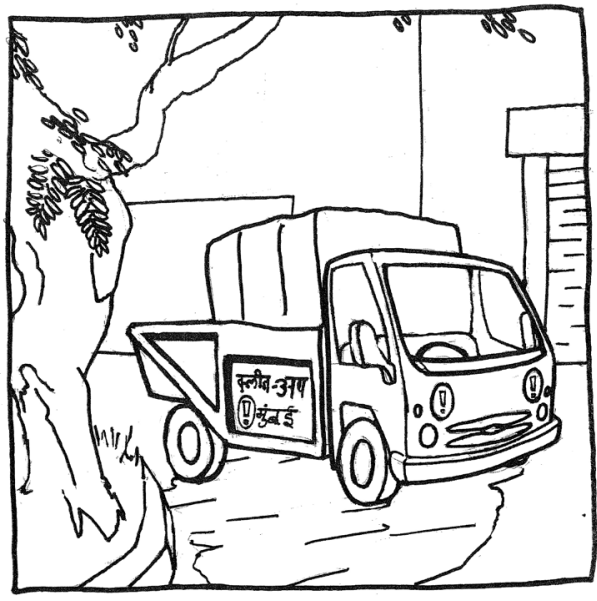

Color in the Trash Iruek
Aaron Fine is Professor of Art and Gallery Director at Truman State University where he also teaches in the Interdisciplinary Studies program. His recent creative non-fiction on subjects in visual culture has been presented at several Popular Culture and Asian Studies conferences and in three forthcoming publications. His paintings and drawings have been exhibited widely over the past 20 years. 


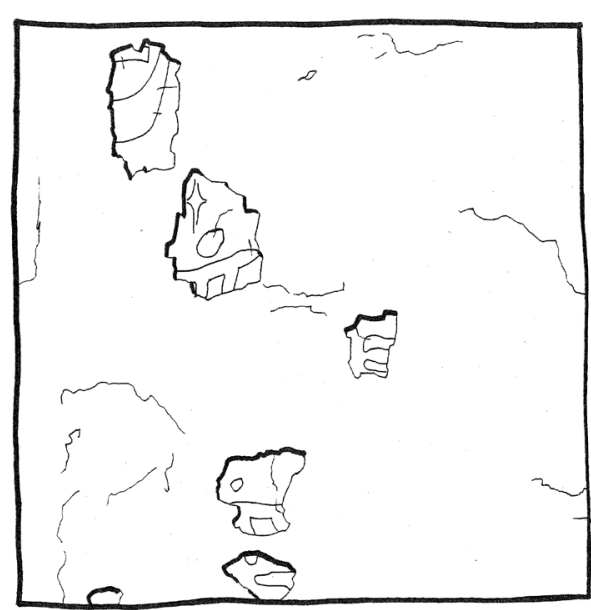

Color in the Palimpsest behind the wall converge with the public right to expression in the space outside the wall? When it gets down to it, does that mural on the wall represent the views of those who live behind it, or the public in that neighborhood, or some other entity?

But when I got to Mumbai almost all of the painting that I had seen on previous visits was gone. In its place were blank walls and a new plague of cheaply produced, poorly designed digital banners. These are printed by the thousands on a synthetic fabric of no use to anyone beyond this momentary function as a banner. While the walls

and canvas banners of old were repainted, reused and repurposed many times over, the new, digital prints go straight to the landfill after performing their one-time-only purpose. This essay is a reconstruction of what I learned that summer in Mumbai, about political graphics and sign painting in general.

For the most part I met a wall of incomprehension or obstruction when I set about asking my questions. Some of this obstruction arose from those who wished to control political expression, and some came from those who sought to protect me from any trouble I might stir up. This work raised many doubts for me about the usefulness of notions of truth when describing complex social decisions about who does and doesn't get to make use of the visual landscape of the city.

Sitting on the low concrete wall that circles Shivaji Park, I alternate between watching men enter the gym to lift weights and gazing up at the stylish midcentury apartment buildings that line the opposite side of the street. Far across the open space where boys are playing cricket, and where on occasion huge political rallies are held, rises the equestrian statue of Shivaji. The park is named after this 17 th century ruler of the people of Maharastra, who battled the Mughal emperors and whose name is invoked by today's Hindu nationalists in their efforts to stoke anti-

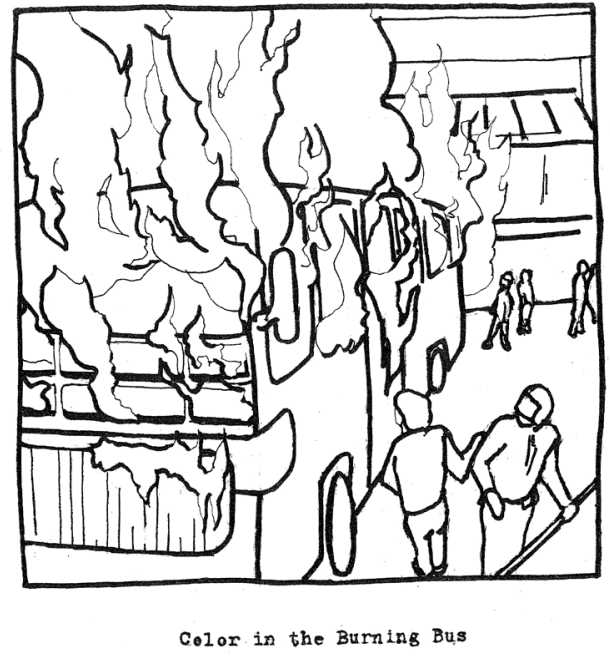
Muslim sentiment.

I've selected a shady spot where I can keep my temperature steady, and from where I've been able to watch the two police officers, lounging at their post on the corner. They are there watching over a more recent statue, and they have erected an awning to protect themselves from the sun. This statue is a bust of Meenatai Thackery, the wife of the founder of the Shiv Sena political party. "Shiv Sena" means "Army of Shivaji," and many describe them as a goon squad of extortionists, thugs, and arsonists. This quiet, prosperous neighborhood is ground zero for many political tensions in the region. A year or two before, someone smeared mud on that bust of Meenatai and the city was shut down by the ensuing riots, 
including burning busses. Thus, today this icon has a 24-hour armed guard, courtesy of the city police. And they are not letting me take my picture of the bust. I am hoping that when my translator, Nikhil, arrives he can convince them to let me take pictures. But he is late.

Finally, almost an hour late, Nikhil does arrive. Walking up with a youthful slouch, he apologizes, blaming Mumbai's trains for the delay. We begin talking about my project, and it takes a while to reach an understanding about what I intend to find out. When it finally dawns on him he says, "No, don't ask those questions." It occurs to me that I am being a bit naïve about local politics and just how sensitive these questions are in a city where intimidation is a commonplace political tool. Nikhil is convinced that my questions will not get any honest answers. On the contrary, they will put him in danger. No shopkeeper will want to be asked, "Who put the painting of the tiger on your wall?" or "Did you ask for that painting to be put there?" or "Whose idea was it?," "Who paid the sign painter?," or "Did you put it there to show your support of the Shiv Sena?" Asking such questions would amount to saying "What group of thugs do you pay off for protection in the event of social unrest?"

As a compromise, Nikhil does agree to talk to the police for me. We walk over and greet them. He explains who I am, that I am here to study the city's signage, my interest in other political displays such as the statue of Meenatai Thackery, and my desire to photograph it for my research. They listen, frown, and shake their heads, gesturing for us to leave. Nikhil suggests that we just drive by and take a picture before they can stop us. He seems to be warming up to our project - to the notion of shining a light on that which is hidden. But this time, I shake my head. "No thanks," I say. "It's not that important." I know the photos I want are available on the internet. Nikhil and I see the irony in this situation - why would the police prohibit photographs of an artifact whose image is widely available? But the police do not seem to be in the business of appreciating irony.

So now what?

We stand beneath art deco balconies on a street unusually free of improvised shelters for the homeless. We bat around some ideas and finally Nikhil says he knows some folks in politics. These people might help me talk to someone within one of the parties. His friends live in Daravi, Asia's largest slum. He makes a couple of phone calls, and then he says, "Let's go."

I can understand why the ragpickers are not too concerned about that new trash service honing in on their livelihood. There is, after all, a lot of trash to go around. And I also imagine that the new, disposable, western-style materialism creates a lot of trash the ragpickers simply can't use. On the other hand, when garbage cans were introduced to turn-of-thecentury Paris, their inventor was accused of heartlessness for depriving the poor of an important livelihood. My own impression is no one really knows what sorts of disclocations these efforts to modernize will bring about, and no one seems to care.

Daravi is a 100-year-old slum, built by squatters on swamp land and gradually filled in. Today it is a concrete maze, the occupants having obtained the legal right to stay decades ago. And it is also a vast vote bank, crucial to election-year outcomes. Much of the industry inside Daravi is based on recycling. But much of what is not recyclable is piled onto an endless stream of trucks and hauled out of the slum. It doesn't get very far. I've watched it being hauled across the highway and dumped into more swampy areas adjacent to Daravi. I've watched these wetlands being transformed into a vast landfill - soon to be new real estate. And real estate, in a city where half the population is homeless, is worth an awful lot of money. 
When I look around at the material culture of India I am "taken" by its improvised nature. This "taken-ness" is more about my own experiences of being surrounded by the standardized products of mass production than it is about Indian culture. It is easy to slip here into dichotomies wherein the colonized is described as "clever" and "resourceful" but perhaps also "quixotic," or even "sloppy." Nevertheless, I am fascinated by every bathroom I walk into and am under the impression that each and every one was made on the spot by a creative plumber with limited resources. Bathrooms are, of course, only one example of the myriad urban environments cobbled together and modified by individual workers. Everywhere I turn in Mumbai, I see a material culture that is profounding different from the one in which I grew up. In Kansas City (or any other U.S. City), one is surrounded by very few hand-made objects. In contrast, many of the objects in a city like Mumbai exhibit some evidence of the hand of the person who created or installed them. And even though the signs and fixtures may operate in the same manner, there is a vast difference in the material culture of these two environments. Mumbai is evidence that if human labor is cheap enough, the industrial revolution can be set on pause indefinitely. There is no need to automate or mechanize processes in order to save money on labor when labor itself is so astonishingly cheap.

If all of this is true of material culture, then it is of course true of hand-painted graphics as well. My training as an artist enhances my response to improvised material culture like hand-painted signs. My natural response is to adore the evidence of the artist's hand in what locals regard as completely innocuous or perhaps even ugly, mundane signage. But I also know that painting these signs is (or was) someone's livelihood. These artists combined hand skills with knowledge of visual culture and an entrepreneurial knack for working fast. In India: A Million Mutinies Now, V.S. Naipaul writes, "The shops, even when small, even when dingy, had big, bright signboards, many-coloured, inventive, accomplished, the work of men with feeling for both Roman and Sanskrit ... letters." We can turn on an old black and white movie from Hollywood such as the Maltese Falcon, and watch the sign painters changing the text on an office window, and recall a time when such craftspeople left their mark in our cities as well.

My attempted interviews in Daravi were fruitless. Or the fruit they bore were too predictable to be of interest. The party operatives were creepily self-important and gave the answers one knew they would give. Bal Thackery, the leader and founder of the Shiv Sena party, is a general. The party is an army. Orders are given and carried out. So, for these soldiers, my questions like "why" they once hired sign painters and "whether or not" going digital is cheaper are neither here nor there. For them the bottom line is to do what they are told, to show their solidarity, their loyalty, and to exhibit the force of that unity in all that they do.

More interesting things happened after Nikhil and I left.

Standing in the rain, in the dark, in a concrete maze, I intuit that it is time for me to reintroduce the topic of payment. Yes, Nikhil has finally admitted, after the

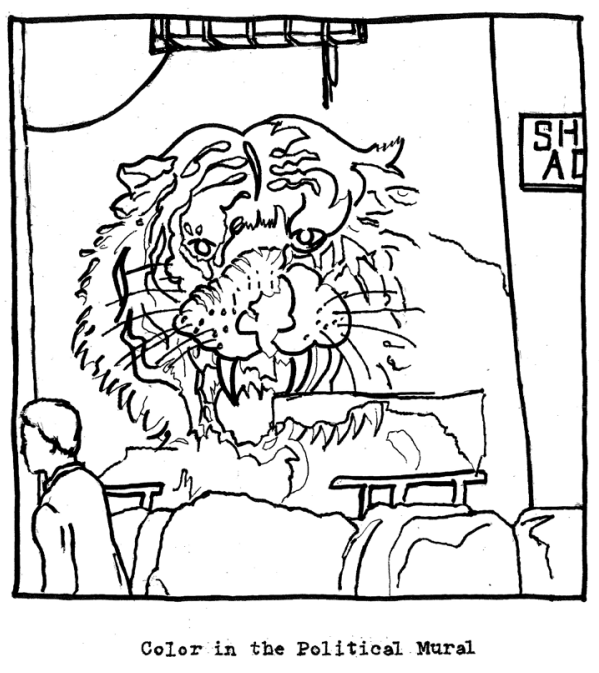


fact, that we need to pay for the privilege of speaking with the politico. I don't know for sure where the money will go. In theory, it goes to the "good causes" in which the party is involved. More likely, however, is that various hands take all of it - with the main man getting the bulk. Perhaps even my interpreter gets some? But he seems so pained by all this, not to mention that the company who provided his services strictly forbids any transaction like the one we are engaged in. I tell him it's ok, but he protests.

"No, exactly this kind of thing is very bad." His face looks oddly tight now. I realize that it kills him for me to see him, his culture, and his country, in this light. "This corruption, it's..." He mumbles a bit. "Let me tell you how it goes. You could see how that office was jammed between two buildings. That must have been an alley once. They (the people who work for the Shiv Sena) just built there and someday he will move his mother in there and no one will say anything." The office he is describing is a concrete room with a couple of bare fluorescent tubes on the ceiling, a desk at the back end, and two benches along the sides in front. Maybe 6 feet by 9 - about the size of a home in Daravi for 4 to 8 people.

Nikhil continues to tell stories to pass the time, and comments again on our predicament. "A while back, the Shiv Sena found a spot against a building where they hitched a cow. The cow is sacred and no one messes with it. Soon they say the cow needs shelter so they build a roof over it. Then it's a room and then one day the cow is gone and they have a new apartment attached to the side of the building." Nikhil flashes a smile. Story complete.

My interpreter's tale confirms my own thoughts about the interview and about my foolish questions regarding who painted the signs and who gives permission for painting them - who decides and who asks. Instead, I have realized, there is no asking and no permitting. None of the political visual culture I have studied in India - the flags, banners, murals, statues and so on - are the kinds of grass roots political expression my questions presuppose. They are instead markers of who has power in the visual landscape.

I decide to give a low guess as to how much money I should offer the neighborhood party boss: 100 rupees (about 2 dollars). He gives me an exasperated look that says, "Why are you making this worse than it already is?" So I say, "Right, I thought that might be too little. How about 500 rupees?" Rain falls on the folded paper notes as I pull out my money and hand it to Nikhil. One of the sophisticated teenagers hanging around runs over. $\mathrm{He}$ takes the money, puts the cash in his pocket, and disappears into the rain. Perhaps five minutes pass. I worry that my wife is concerned about me. Then someone gives us the word - we may now leave. My helpers (Nikhil, Nikhil's friends, and other young men who simply showed up) ascertain my remaining wealth, give the bulk of it to a cab driver, and bundle me off to my home on the other side of the tracks.

Imagine me in Mumbai on a sunny morning in July. I walk up and down a residential street in a middle class locale looking for the home of a former Bollywood billboard painter. I am not lost but I am also not finding my destination. There are no house numbers, no street signs, and no way to find your way around if you are not from this neighborhood. I am about to give up and walk home when I hear him call my name, lengthening the "A" sound into "Ah-aron!" I am surprised when he comes near; he is younger than I expected. He greets me like a westerner, shaking my hand.

"Oh yes, my father could not be here. I am Sushant. I am in the family business as well. I will answer your questions." Accepting this substitution, as apparently I must, I follow him into a nearby building and up 2 or 3 flights of stairs. The flat is reasonably spacious and very clean, more aesthetically pleasing than most Indian apartments. A large circular window looks out onto the street. 
Against one wall leans a large canvas, a half-finished copy of a painting by Rousseau - a commissioned project for a client. The young man talks about his work on this and other jobs with clear enjoyment. He speaks to me in the familiar way painters do with one another about the desire to paint. I have learned about his family through an article in the Hindustan Times, a national newspaper. The article described a family who, having painted Bollywood billboards for 40 years, now makes money by painting portraits of Europeans in the Bollywood manner. I need to discern whether Sushant knows about the painting of political imagery and whether, perhaps, his family did that as well.

"Yes, we did both," Sushant responds. "Mostly movie billboards, but also politicians. They were the same." He offers me tea and biscuits and shows me the family photo album with discolored photographs of some of the work they have done over the years. "We employed about 30 people, would sometimes work on hundreds of canvas banners for the same movie. The tallest could be 3 or 4 stories high. My father started in '69, opened his own business in '79. He trained under Shoiab Diwaker and we did jobs for Rajshri Productions and Yashraj films, and also Sharuk Khan movies." These are names even I have heard of - some of the biggest production companies in Bollywood.

I ask about the digital banners and their impact on the industry. "It started to happen in ' 99 or 2000 . But then by 2003, it was all over. We couldn't believe. It was really difficult. The whole industry just went away." I ask if he figures this is because digital banners are cheaper to produce. "Of course, even at low wages, paying for all those work hours when you could just print them out instead at 10 rupees per square foot."

I agree with him, though I know that printing isn't the newcomer technology. In fact, I later read a Times of India (another

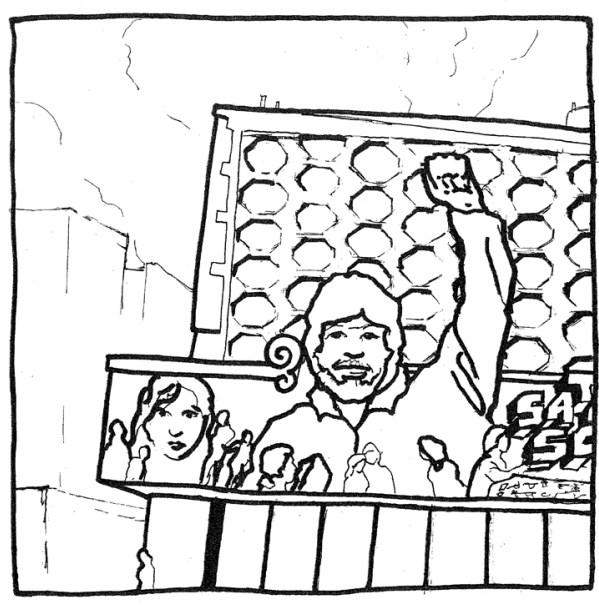

Color in the Bollywood Btllboard major daily newspaper) article about workers in Kerala, India being paid to paint murals of communist icons. Admittedly, the economic system in Kerala is vastly different than the Darwinian free-for-all of Mumbai. Kerala has often had a communist-led government, and thus might be expected to commission sign-painting as a jobs-creating effort. But even if digital technology doesn't turn out to be cheaper than hand painting, it offers benefits besides economy. It democratizes design - or fools us into thinking anyone can design and it makes the whole process of working collaboratively with images much more fluid. Also, it is a sign of being up to date.

"So what did you do?"

"Most people just disappeared. They are doing something else now. We've [Sushant's family] been lucky. We've found ways to make a living, like in that article." He tells me about going to London, where they made a painting for an Asian culture festival. He shows me the photo of his father and others, standing by the lions in Trafalgar Square on a cold day with their colossal painting behind them, rigged up as a backdrop for a dance stage.

"And all these canvasses, the billboards, where are they now?"

"Gone. We would repaint over them quite a bit, though eventually they got so you couldn't use them. Other people used them afterwards - as tarps."

"So all those millions of paintings - are in the garbage or being used as tarps now?" 
"Sure, they can be roofing in a shantytown. Or a covering for a truckload of goods."

"That art would be worth so much now."

"I know. And people make fakes - and make them look like they are old. There was an exhibit of this art at Osian Auction House and Gallery, and in 2007 at the Jehangir Gallery. We were never contacted, nor were the other families we know from the business. But we were curious so we went to see. And we could tell that all these paintings were made new, for that show."

"So the work is gone. And most records of it. And most of the remains are fakes," I said. He nodded, showing me his disgust with a shake of the head.

"Yes. People don't care, though, about these things. Nobody even has a notion of what could be wrong."

"And the new banners, the digital printouts?"

He waves the back of his hand at the window, dismissing the signs, the streets, the people on the other side of the glass. "No one even has eyes."

My research project originally rested on a few naïve suppositions. One was that the hand-painted graphics of the city had any correlation with the graffiti of the west. It turns out that these were the products of industry and power, not vandalism or the voices of the powerless. And their replacement by digital printing, while representing a fundamental shift in the makeup of the visual landscape and altering the relationship of visual culture to the waste stream, may not have involved any loss in political participation. This story is intentionally presented with the limitations of my own perspective in place. Other researchers have immersed themselves more fully, given these subjects more time, and deserve recognition for their hard-won insights. The excellent website, Tasveer Ghar http://www. tasveerghar.net/), and its essay on K. Madhavan, “The Norman Rockwell of South India," by Stephen Inglis, have guided and inspired me.

Virtually the only person I met in Mumbai who really understood my project was Sujata Anandan, the Political Editor for the Mumbai edition of the Hindustan Times. I learned a lot from her about the development of the Shiv Sena and even about visual political culture. For whatever reason, the industrialization of printing 100 or more years ago did not drive out handcrafted graphics from India. Sujata understood that, with several exceptions, the digital has finally accomplished this. Digital media has penetrated to the smallest hamlets in Maharastra. Top-down political communication is thus facilitated in a way that is much more fluid, immediate, speedy, and temporary than before.

So the trend is this: the institutional, commercial, and political Bollywood-style street graphics of the late 20th century have given way to a more flexible, rapid, and disposable medium. This form of expression appears to be just as undemocratic as did those older paintings. That is to say, neither the old way of painting signs nor the new way of producing them digitally is the kind of political expression that a western observer like myself might associate with graffiti or independent political protest.

The trend towards the institutionalized and commercialized creation of signage in Mumbai coincides with an effort to westernize trash services in the city - substituting a cheap disposable material culture for a more durable and reusable one. Part of that cleanup effort appears to be the growing tendency to quickly paint over any writing on walls in public spaces - substituting uniformity for the hodge podge of visual expression that once was there. The wall, being the space where private property rubs up against the public visual environment, is being reclaimed by those who own it. Meanwhile, the visual environment is filled with digital garbage. 
Most of the people I spoke with in Mumbai were unconcerned with, or even unaware of, the sudden proliferation of actual trash in their visual culture. Perhaps as a global culture we can all nourish the capacity to weigh the relative visual richness or impoverishment of the materials and processes we use for visual communication. The coloring book plates that accompany this essay are of my own making. They invite you to remember and reinscribe the evidence of the human hand onto the whitewashed spaces of the city. 